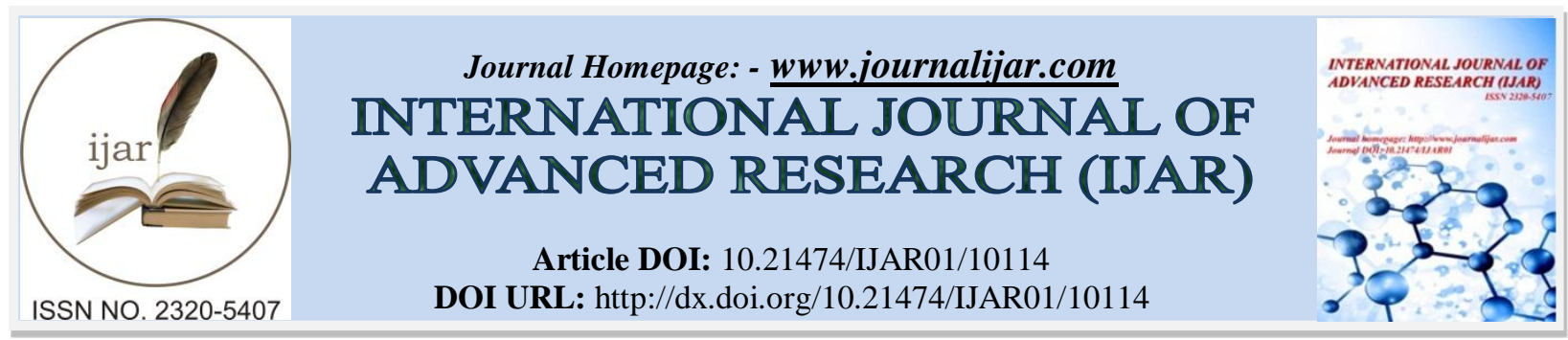

RESEARCH ARTICLE

\title{
HEALING OF WOUND WITH SPECIAL REFERENCE TO UTSADANA - A CRITICAL REVIEW.
}

\author{
Dr. Jyoti Shinde ${ }^{1}$ and Dr. Subhash Raut ${ }^{2}$. \\ 1. PhD Scholar, Dept. of Shalya-Tantra, Govt. Ayurved College, Nagpur. \\ 2. PhD Guide, Professor\& HOD, Dept. of Shalya-Tantra, Govt. Ayurved College, Nagpur.
}

\section{Manuscript Info}

\section{Manuscript History}

Received: 14 September 2019

Final Accepted: 16 October 2019

Published: November 2019

Key words:-

Shasthi Upakrama, Utsadana, Collagen synthesis, Granulation.

\section{Abstract}

Aim and Objective: To define the term 'Utsadana' described under Shasthi-Upakrama of Vrana in Sushrut Samhita.To explore the basic principle of wound healing in context to Utsadana.

Methodology: References regarding the term Utsadana are collected from Sushruta Samahita and other Ayuvedic classics. Modern textbooks of surgery were also referred to understand the wound healing process in detail. An attempt is made to define the term Utsadana and discuss Utsadana karma on the basis of modern medical sciences. A very limited conceptual work has been carried out on Shasti-Upakrama for Vrana, mentioned by Sushruta. It is the need of hour to explore and elaborate the knowledge of wound and its management at different stages of wound healing stated in Sushrut Samhita. Utsadana karma is one of the Shasthi-Upakrama stated by Sushruta for the management of Vrana. Dalhana described Utsadana karma as an important karma for enhancing wound healing. In the chapter Dvivraniya, he has described Utsadana as an elevation of the floor of the wound, causing a wound to fill up and any application applied to a wound producing granulation is termed as 'Utsadaneeya. Utsadana karma is an intermediate procedure between Shodhana and Ropana karma. An attempt is made to correlate the term Utsadana with granulation formation in modern surgery.

Conclusion: It is concluded that Utsadana is a stage in process of wound healing and may be identical to the stage of granulation formation.

Copy Right, IJAR, 2019,. All rights reserved.

\section{Introduction:-}

The art and science of surgery revolves round the 'Vrana' (Wound). While explaining the scope of 'Shalya-Tantra', Sushruta mentioned- 'Vrana Vinischayartham'as a major part of Shalya-tantra.

He has vividly described concept of Vrana, its aetio-pathogenesis, various classifications of Vrana and management of Vrana during various stages, which is of prime importance and is the basic of the whole surgery. The fundamental principles and techniques described in aphorism form by Sushruta for the management of Vrana retains landmark position in the field of surgical practises even today and are still relevant in day-to-day practice.

Corresponding Author:-Dr. Jyoti Shinde.

Address:-PhD Scholar, Dept. of Shalya-Tantra, Govt. Ayurved College, Nagpur. 
A very limited conceptual work has been carried out on Shasti Upakrama described by Sushruta in Sushruta Samhita.Sushruta advised 60 different procedures for the management of Vrana, in a very simple and scientific manner, further these have been summarized to 7 procedures of Vranashopha. These 60 procedures play significant role in healing of wound.

Thus, it is the need of hour to explore and elaborate the knowledge of wound and its management at different stages of healing mentioned by Dalhana in his commentary Nibandhasangraha on SushrutSamhita.

The present study is aimed to interpret the term Utsadana defined by Sushruta. He has referred this term while discussing the process of healing of wound and modalities of management to facilitate the healing process. But efforts were made only to highlight terms like Shodhana and Ropana, in spite of the significant role of Utsadana i.e. the process of proliferation which encompasses angiogenesis, collagen synthesis and granulation.

\section{Aim and objective:-}

To define, explore and discuss the term Utsadana - one of the Shasthi Upakrama mentioned in Sushrut Samhita.

To explore the basic principle of wound healing in context to Utsadana

\section{Material and mathod:-}

All the references regarding the term 'Utsadana' are collect from Sushruta Samahita and other Ayuvedic classics. Modern textbooks of surgery were also referred to understand the wound healing process in detail. An attempt is made to define Utsadana karma on the basis of modern medical sciences.

\section{Observation:-}

Healing of the wound is the oldest phenomenon discussed in medical literature. It is a very dynamic and complex process. The same events in the same order occur in every healing process, regardless of the tissue type, or the inciting injury. ${ }^{2}$ Various types of cells including neutrophils, lymphocytes, macrophages, keratinocytes, fibroblasts and endothelial cells are involved in this process ${ }^{3}$.The wound healing starts with haemostasis at the site of injury, then progresses to an inflammatory phase which is then followed by proliferation of new tissues and ends with the formation of scar tissue marked by lay down of a highly organized collagen matrix. ${ }^{4}$ The process of wound healing can be divided into four overlapping phases.

Haemostasis (blood clotting): Within the first few minutes of injury blood vessels constricts and seal them off as platelet plug is formed at wound and vessels end which halts the bleeding. They change shape to enhance clotting with release of chemical signals to promote clotting. This results in the activation of fibrin, which forms a mesh and acts as "glue" to bind platelets to form platelet plug. All this process eventually prevents the further bleeding.

Inflammation: This process involves clearance of damaged and dead cells, bacteria, and other pathogens and debris. In this process white blood cells engulf debris. This process is called phagocytosis. There are many growth factors which are released into the wound that causes the migration and division of cells during the proliferation phase.

Proliferation (growth of new tissue): In this phase, angiogenesis, collagen deposition, granulation tissue formation, epithelialisation and wound contraction occur. In angiogenesis - vascular endothelial cells form new blood vessels. In fibroplasias-fibroblasts grow and form a provisional extracellular matrix (ECM) by releasing collagen and fibronectin. Again Re-epithelisation of the epidermis occurs in which epithelial cells proliferate and covers the wound bed. In wound contraction, Myofibroblasts decreases the wound size by gripping the wound edges. Collagen is synthesized by fibroblasts. It is the most abundant protein in human body. This component provides the strength and integrity to all the tissue, especially the healing wound.

Maturation (remodelling): As the name suggests collagen is realigned along the tension lines and unnecessary cells are removed by programmed cell death or apoptosis.

Wound healing is very complex and fragile process which is susceptible to failure or interruption leading to the formation of non-healing chronic wounds. Various factors, extrinsic and intrinsic to the wound, affect the wound healing process. ${ }^{5}$. Though proper wound care speeds up wound healing by protection from infection and reinjures, the wound can be manipulated by using certain techniques to accelerate the healing. 
In Ayurveda, Sushruta described phases of wound healing in detail as below -

Dushta Vrana ${ }^{6}$ (Infected or untidy wound): According to Sushruta, Vrana which is too narrow or too wide mouthed, extremely hard or soft, elevated or depressed, hot or cold to touch, black/red or yellow/white in colour, exhibits strange and unusual features, filled with putrid and sloughing and fetid pus, indefinite and irregular in shape, pain, burning sensation, swelling, redness, itching and suppuration and pustules with secretion of vitiated blood, is considered to be Dushta Vrana.

Shuddha Vrana ${ }^{7}$ (Wound with healthy granulation): The wound which is not invaded by Tridoshas, edges are bluish in colour, with even granulation tissue and absence of pain and exudation is considered to be Shuddha Vrana.

Ruhyaman Vrana ${ }^{8}$ (Healing wound, collagen formation and epithelisation): The wound having a grey colour (colour of pigeon), devoid of exudation, has scales of skin adhering firmly, having scab formation, is to be considered as healing.

Samyak Rudha Vrana ${ }^{9}$ (Properly healed wound) : The wound which has healed in its own tissue, which has no eruptions, swelling or pain, has the colour same as that of the skin and which is at the level of normal skin, is to be considered as healed.

In chapter Dvivraniya, Dalhana has described the term Utsadana as an elevation of the floor of the wound, causing a wound to fill up by tissues ${ }^{10,11}$, and 12 . In Ayurveddipika - a commentary on Charak Samhita, Chakrapanidatta also described the term Utsadana as a procedure that elevate the deep floor of wound in order to accelerate the healing ${ }^{13}$. Thus the term Utsadana can be correlated with the stage of proliferation of new tissues i.e. angiogenesis, collagen synthesis and granulation formation.

\section{Indications for Utsadana ${ }^{14}$ -}

Utsadana is indicated in those wounds which have 'ShuskalpaMaansa'- a very little of dried out muscle tissues and the wound which is 'Gambheer'. Here we can correlate the term 'ShuskalpaMaansa' with the wound having no granulation or unhealthy granulation tissue, and the term 'Gambheer Vrana is correlated with the wound which is deep seated. In such kinds of wounds, it is beneficial to elevate the wound floor by performing Utsadanakarma, for which some drugs are described in Ayurveda, which are termed as Utsadaneeya.

\section{Utsadaneeya:}

Utsadaneeya are those drugs or materials that help to fill up the wound. Here the term Utsadaneeya can be correlated with the drugs or materials that accelerate the process of angiogenesis, collagen deposition, granulation tissue formation, in wound healing.

\section{Drugs used for Utsadana:}

1. Various drugs are mentioned in Ayurveda for Utsadana karma -

2. Lepa of Apamarga, Ashwagandha, Talpatri, Suvarchala and drugs from Kakolyadi Gana processed in ghruta ${ }^{15}$.

3. Nyagrodha, Padmaka, Ashwagandha, Bala, Tila, Meat of carnivorous animals, prepared in proper manner ${ }^{16,17}$.

4. Drugs from Stanyani, Jeevaniyani, Bruhaniyani Ganas ${ }^{18}$

5. Drugs like Trivritta, Tila, Nagdanti, Manjishtha processed in payasa along with Saindhav and kshaudra ${ }^{19}$

\section{Routes of administration of Utsadaneeya drugs:}

Utsadaneeya drugs are administered by local application as well as by oral route.

Local application (Lepa or Aalepana) 20, 21: Utsadaneeya drugs processed with Ghruta were used for topical application (lepa / aalepana) on the wound.

Oral administration ${ }^{22,23}$ : Also to accelerate the process of healing; there are references of oral administration of flesh of carnivorous animals like Vyaghradi etc. and the drugs from Stanyani, Jeevaniyani \& Bruhaniyanigana, which enhances the synthesis of protein and ultimately collagen synthesis.

\section{Discussion:-}

There are two main components of the process of proliferation - Granulation formation and Epithelisation. Granulation takes place in upward direction from the base to the top of a wound aimed to fill up the wound, whereas 
epithelialisation occurs from periphery (from edges) towards centre in order to cover the wound. Granulation formation is nothing but the process of Utsadana, whereas Epithelisation is a process defined as VranaAcchadana ${ }^{24}$ while defining the Vrana by Sushruta in Ayurveda. Dalhana has also stated the concept of Uparudha Vrana and Rudha Vrana in chapter of Bhagandar Chikitsa.He stated that after complete healing of fistula tract, recurrence may occur as the wound is in Uparudha condition. ${ }^{25}$ Uparudha is the stage of wound healing where the wound is covered and closed by epithelialisation, but still the tissues are not matured optimally. This under-matured tissue doesn't have optimal level of elasticity and tensile strength. Hence there is a chance of getting tear due to strenuous work. It requires the period of a year to get Rudha or optimally matured

Various stages of wound healing in modern medical sciences can be compared with the terms used in Ayurveda for wound healing.

1. Stage of granulation tissue formation= Utsadana

2. $\quad$ Stage of epithelialisation $=$ Vrana Aachchadana

3. Stage of scar formation and resorption= Uparudha

4. Stage of maturation $=$ Samyak Rudha

From the above, it can be interpreted that Utsadana is nearly similar to the stage of granulation tissue formation while discussing the process of wound healing.

Charaka and Sushruta have mentioned total 36 and 60 Upkramas respectively for wound healing. Sushruta has described almost all the fundamental principles of basic surgery in a very aphoristic form in the chapter Dvivraniya Chikitsa under the heading of ShasthiUpakrama. ${ }^{26}$ Amongst them, Utsadana is one of the most important upakrama. In spite of a major role of Utsadana during the process of healing, Ayurvedic text did not mention its exact occurrence at the appropriate level of healing process. Though Utsadana plays an important role in wound healing, the emphasis is being given to the Shodana and Ropana upakramas, leaving aside the important process of Utsadana. Only it was Dalhana, who highlighted in his commentary on Sushrut Samhita in chapter Bhagandar chikitsa that Utsadana is an intermediate process which occurs in between Shodhana and Ropana karma during wound healing. ${ }^{27}$ It was observed in certain study that, fibroblast cell count, epithelial cells and synthesis of extracellular matrix extracellular matrix including collagen synthesis is increased by aqueous and ethanol extract of Achyranthus Aspera $(\text { Apamarga })^{28}$

In another recent researches, In vivo studies shows with the use of 5\% (w/w) methanol extract of Achyranthes Aspera there is well organized epidermal layer, increased no of fibrocytes, remarkable degree of neovascularization and epithelisation ${ }^{29}$.

Furthermore, another in vivo study showed an enhanced rate of wound contraction and a drastic reduction in healing time, which might be due to enhanced epithelisation which can be directly measured in terms of days for complete closure of wound. Increase in the protein and collagen content is responsible for the enhanced migration of fibroblasts cells, epithelial cells and synthesis of extracellular matrix including collagen during the healing process ${ }^{30}$

\section{Conclusion:-}

Thus from above studies, it is conclude that Utsadana karma is a stage in process of wound healing and may be Identical to the stage of proliferation of new tissues i.e. angiogenesis, collagen synthesis and granulation.

Utsadaniya dravyas like Apamarga, Ashwagandha, Talpatri, Suvarchal etc. perform Utsadana Karma in wound healing by enhancing the synthesis of proteins and ultimately collagen synthesis.

\section{References:-}

1. Sushruta, Sushrut Samhita, Dalhana's Commentary, Su. Su. 1/8, P.V. Sharma, Chaukhambha Vishvabharati,Varanasi,2018, page- 8

2. Courteny M. Townsend,R. Daniel Beauchamp, B. Mark Evers, Kenneth L. Mattox,Sabiston Text Book of Surgery, $17^{\text {th }}$ edition, Elsevier India, page $184-184$

3. Guo S, Di Pietro LA.Factors affecting wound healing. J Dent Res 2010; 89:29- 21

4. Velnar T, Bailey T, Smrkoi JV. The wound healing process: an overview of the cellular and molecular mechanism.Int Med Res 2009; 37:1528-42. 
5. Kumar V. Abbas AK, Fausto N, Aster JC.Inflammation and repair. Robbins and Cotran Pathologic Basis of Disease.9th edition.Philadelphia:Elsevier Saunders;2014.p69-110

6. Sushruta, Sushrut Samhita, Dalhana's Commentary, Su. Su. 22/8,P.V. Sharma, Chaukhambha Vishvabharati,Varanasi,2018, page-241

7. Sushruta, Sushrut Samhita, Dalhana's Commentary, Su. Su. 23/18,P.V. Sharma, Chaukhambha Vishvabharati,Varanasi,2018, page-250

8. Sushruta, Sushrut Samhita, Dalhana's Commentary,Su. Su. 23/19, P.V.Sharma, Chaukhambha Vishvabharati,Varanasi,2018, page-251

9. Sushruta, Sushrut Samhita, Dalhana's Commentary, Su. Su. 23/20, P.V. Sharma, Chaukhambha Vishvabharati,Varanasi,2018, page-251

10. Sushruta, Sushrut Samhita, Dalhana's Commentary,Su.Chi.1/81-82,Jadhavji Trikamji Acharya,Chaukhambha Sanskrit Sansthan, Varanasi,2017,page 404

11. Sushruta, Sushrut Samhita, Dalhana's Commentary,Su.Chi.8/40,Jadhavji Trikamji Acharya,Chaukhambha Sanskrit Sansthan, Varanasi,2017,page 441

12. Sushruta, Sushrut Samhita, Dalhana's Commentary, Su.Su. 37/30,Jadhavji Trikamji Acharya,Chaukhambha Sanskrit Sansthan, Varanasi,2017,page 163

13. Charaka, Charak Samhita, Chakrapanidatta:s Commentary Ayurved Dipika, Cha. Chi. 25/37

14. Vagbhata, Ashtang Hriday, Arundatta's commentary - Sarvangasundar, Uttar Tantra Chi.25/46, page 864

15. Sushruta, Sushrut Samhita, Dalhana's Commentary,Su. Su. 37/30, P.V. Sharma, Chaukhambha Vishvabharati,Varanasi,2018, page 163

16. Vagbhata, Ashtang Hriday, Arundatta's commentary - Sarvangasundar, Uttar Tantra Chi. 25/46, page 864

17. Vagbhata, Ashtang Hriday, Arundatta's commentary - Sarvangasundar, Uttar Tantra Chi. 25/46, page 864

18. Charaka, Charak Samhita, Chakrapanidatta:s Commentary_-Ayurved Dipika, Cha. Chi. 25/99

19. Sushruta, Sushrut Samhita, Dalhana's Commentary,Su.Chi.8/40,Jadhavji Trikamji Acharya,Chaukhambha Sanskrit Sansthan, Varanasi,2017,page 441

20. Sushruta, Sushrut Samhita, Dalhana's Commentary, Su. Su. 1/82, P.V. Sharma, Chaukhambha Vishvabharati,Varanasi,2018, page 404

21. Sushruta, Sushrut Samhita, Dalhana's Commentary, Su. Chi. 1/16, P.V. Sharma, Chaukhambha Vishvabharati,Varanasi,2018, page 398

22. Vagbhata, Ashtang Hriday, Arundatta's commentary - Sarvangasundar, Uttar Tantra 25/46-47,page 864

23. Charaka, Charak Samhita, Chakrapanidatta's Commentary_-Ayurved Dipika, Cha. Chi. 25/42,

24. Sushruta, Sushrut Samhita, Dalhana's Commentary, P.V. Sharma, Su. Su.21/40, Chaukhambha Vishvabharati,Varanasi,2018, page-239

25. Sushruta, Sushrut Samhita, Dalhana's Commentary, Su. Chi. 8/54, P.V. Sharma, Chaukhambha Vishvabharati,Varanasi,2018, page-357

26. Sushruta, Sushrut Samhita, Dalhana's Commentary, Su. Chi. 1/8, P.V. Sharma, Chaukhambha Vishvabharati,Varanasi,2018, page-24

27. Sushruta, Sushrut Samhita, Dalhana Commentary, ,chi.8/39,e-Samhita-National Institute of Indian Medical Heritage, niimh.nic.in/ebooks/esushruta/?mod=read

28. S .Edwin, E.Edwin, K.R.Dutt, L.Deb, Wound Healing and Antioxidant Activity of Achyranthus aspera.20-012009.

29. "Evaluation of in vivo wound healing activity of methanol extract of Achyranthesaspera L." www.sciencedirect.com/science/article/pii/s0378874112004497; journal of Ethnopharmacology volume 143, issue 2,28 September 2012,pages 469-474

30. S.Edwin et al; E.Edwin, K.R.Dutt et al; "Wound healing and antioxidant activity of Achyranthes aspera"18 April, 2008, 2009,https://doi.org/10.1080/13880200802366645publishedonline:20 Jan. 